\section{Commentary: Surgical aortic valve bioprostheses are still around and looking good}

\author{
Pierpaolo Chivasso, $\mathrm{MD},{ }^{\mathrm{a}}$ and \\ Vito Domenico Bruno, $\mathrm{MD}, \mathrm{PhD}^{\mathrm{b}}$
}

The choice between biological and mechanical prostheses for aortic valve replacement (AVR) remains controversial. The risks related to long-term anticoagulation are intensifying the use of aortic tissue valves, but the structural valve deterioration (SVD) and its impact on durability are still of concern, as they are linked to the potential need for reoperations. However, the good results of surgical reinterventions and the possible benefits of the transcatheter valve-in-valve procedures make the worry about repeated procedures less significant. In this context, it seems appropriate to implant bioprostheses, which potentially could last longer and may be suitable for future transcatheter valve-in-valve procedures.

In the last decade, encouraging results have been accomplished by the RESILIA tissue (Edwards Lifesciences, Irvine, Calif) that has been used to shape biological valve leaflets in experimental models. RESILIA is a bovine pericardial tissue that has undergone a novel method of preservation in which residual aldehyde groups are permanently blocked; the tissue is treated with glycerol, allowing for dry storage and no need for rinsing before implantation. This protective treatment has been related to a significant reduction in calcification and improved hemodynamic performance compared with contemporary leaflet tissues. The early clinical experience with these newly developed valves in aortic position has been positive in the COMMENCE trial: this prospective, multinational, observational study was designed to evaluate the safety and effectiveness of an aortic bioprosthesis with the novel

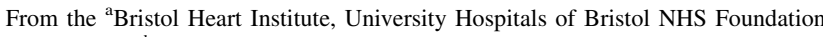
Trust; and ${ }^{\mathrm{b}}$ Bristol Medical School, Translational Health Science Department, Bristol, United Kingdom.

Disclosures: Authors have nothing to disclose with regard to commercial support.

Received for publication Jan 30, 2020; accepted for publication Feb 3, 2020; available ahead of print Feb 14, 2020.

Address for reprints: Vito Domenico Bruno, MD, PhD, Bristol Medical SchoolTranslational Health Sciences, University of Bristol, Research Floor Level 7, Bristol Royal Infirmary, Upper Maudlin St, BS2 8HW Bristol, United Kingdom (E-mail: Vito.D.Bruno@bristol.ac.uk).

J Thorac Cardiovasc Surg 2021;162:1486-7

$0022-5223 / \$ 36.00$

Copyright $($ C 2020 by The American Association for Thoracic Surgery

https://doi.org/10.1016/j.jtcvs.2020.02.026
}

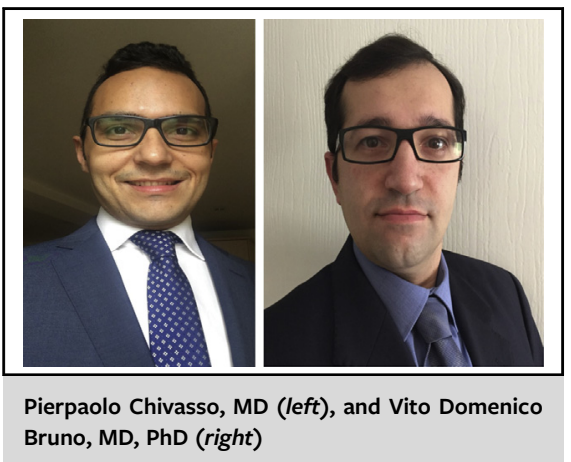

CENTRAL MESSAGE

Surgical bioprostheses continue to improve and new preserving technologies are promising longer durability and clinical outcomes better than ever before.

RESILIA tissue treatment (Edwards Pericardial Aortic Bio-prosthesis, Model 11000A) and enrolled 684 patients undergoing surgical AVR in 27 clinical sites. ${ }^{1}$

In the present issue of the Journal, Johnston and colleagues ${ }^{2}$ present the updated mid-term outcomes of the trial, with a mean follow-up of $3.7 \pm 1.2$ years and a total of 2533 patient years. A study like the COMMENCE trial is always welcome whenever a new valve is developed and tested, and the results confirm a reliable hemodynamic performance and favorable safety outcomes at 4 years, with no reported cases of SVD. With a little incidence of valve-related complications and a very low mortality rate, we can certainly affirm that the valve is reliable and durable at 4 years. The clinical and echocardiographic outcomes are also positive, and there was not a single episode of SVD.

In this sense, the current manuscript is interesting, as it updates the previous findings and we can be reassured that the valve continues to demonstrate good hemodynamic performance and positive clinical outcomes over time. However, one important limitation is the absence of a comparative group, and it would have been valuable to compare these results against other valves not prepared with the RESILIA treatment, but the single-arm nature of the study precludes this type of evaluation. Moreover, it must be acknowledged that SVD is not a very common event in the first few years after biological AVR and similarly calcific degeneration is not expected in the first 4 years of implantation and the authors acknowledge this in their discussion. A previous series of more than 12,000 
patients showed that the actuarial estimates of explant for SVD at 10 and 20 years were $1.9 \%$ and $15 \%$, respectively, ${ }^{3}$ and therefore, with such a low incidence, a longer follow-up is certainly desirable, as it would help to identify possible SVD and the degree of calcifications over time.

The good results of the present paper have been also confirmed by other authors: Bartus and colleagues, ${ }^{4}$ in their series of 133 patients undergoing AVR with RESILIA bioprosthesis, reported no early or late SVD at 4 years and again good hemodynamic performance. Recently, the RESILIA tissue has been also tested in vitro in aortic valve conduit, ${ }^{5}$ and we can imagine that this is going to be the next step for this novel tissue. Investigating a new surgical valve prosthesis in the current era is not an easy task, as this research field is dominated by the transcatheter approach: therefore, studies like the COMMENCE trial are valuable for the cardiothoracic community. Moreover, they contribute to demonstrate that there is still room for improvement in surgical biological valves and efforts toward better technologies are always welcome. The COMMENCE trial is part of these advancements and with such promising results we are excited to see the next study with the long-term results.

\section{References}

1. Puskas JD, Bavaria JE, Svensson LG, Blackstone EH, Griffith B, Gammie JS, et al The COMMENCE trial: 2-year outcomes with an aortic bioprosthesis with RESILIA tissue. Eur J Cardiothoracic Surg. 2017;52:432-9.

2. Johnston DR, Griffith B, Puskas JD, Bavaria JE, Svensson LG. Intermediate-term outcomes of aortic valve replacement using a bioprosthesis with a novel tissue. J Thorac Cardiovasc Surg. 2021;162:1478-85.

3. Johnston DR, Soltesz EG, Vakil N, Rajeswaran J, Roselli EE, Sabik JF III, et al Long-term durability of bioprostetic aortic valves: implications from 12,569 implants. Ann Thorac Surg. 2015;99:1239-47.

4. Bartus K, Litwinowicz R, Bilewska A, Stapor M, Bochenek M, Rozanski J, et al Intermediate-term outcomes after aortic valve replacement with a novel RESILIA $^{\text {TM }}$ tissue bioprosthesis. J Thorac Dis. 2019;11:3039-46.

5. Sadri V, Madukauwa-David ID, Yoganathan AP. In vitro evaluation of a new aortic valved conduit. J Thorac Cardiovasc Surg. November 5, 2019 [Epub ahead of print].

\section{See Article page 1478.}

\section{Commentary: The future of a former valve: Inspiring, resilient, or both?}

\author{
Edward Percy, MD, Morgan Harloff, MD, and \\ Sary F. Aranki, MD
}

Structural valve degeneration (SVD) is the Achille's heel of bioprosthetic valve implantation. Up to $20 \%$ of valves require reintervention by 10 years. ${ }^{1}$ Despite this, there has been increasing use of bioprosthetic valves in young patients, given their favorable hemodynamics, anticoagulation avoidance, and options for subsequent transcatheter valve-in-valve therapy in lieu of reoperative valve replacement. $^{2,3}$ The prevalence of calcific degeneration,

\footnotetext{
From the Division of Cardiac Surgery, Department of Surgery, Brigham and Women's Hospital, Harvard Medical School, Boston, Mass.

Disclosures: Authors have nothing to disclose with regard to commercial support.

Received for publication Feb 7, 2020; accepted for publication Feb 11, 2020; available ahead of print Feb 21, 2020.

Address for reprints: Sary F. Aranki, MD, Division of Cardiac Surgery, Brigham and Women's Hospital, 75 Francis St, Boston, MA 02115 (E-mail: saranki@partners. org).

J Thorac Cardiovasc Surg 2021;162:1487-8

$0022-5223 / \$ 36.00$

Copyright (C) 2020 by The American Association for Thoracic Surgery

https://doi.org/10.1016/j.jtcvs.2020.02.055
}

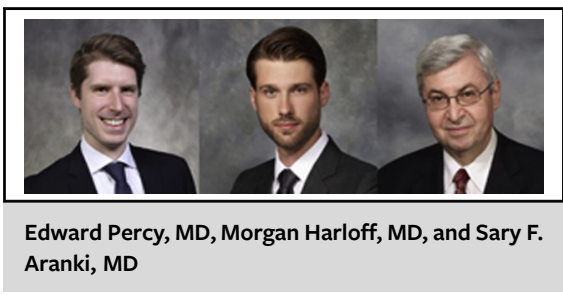

CENTRAL MESSAGE

The COMMENCE Trial examines

a novel bioprosthetic preserva-

tion technique that aims to

reduce calcification and advance

the new frontier of dry storage.

The long-term results are eagerly

anticipated.

which is the most common form of SVD, is therefore expected to increase going forward. RESILIA (Edwards Lifesciences, Irvine, Calif) is a bovine pericardial tissue treated by a novel preservation technique that serves the dual purpose of reduced calcium deposition and dry storage. $^{4}$ 